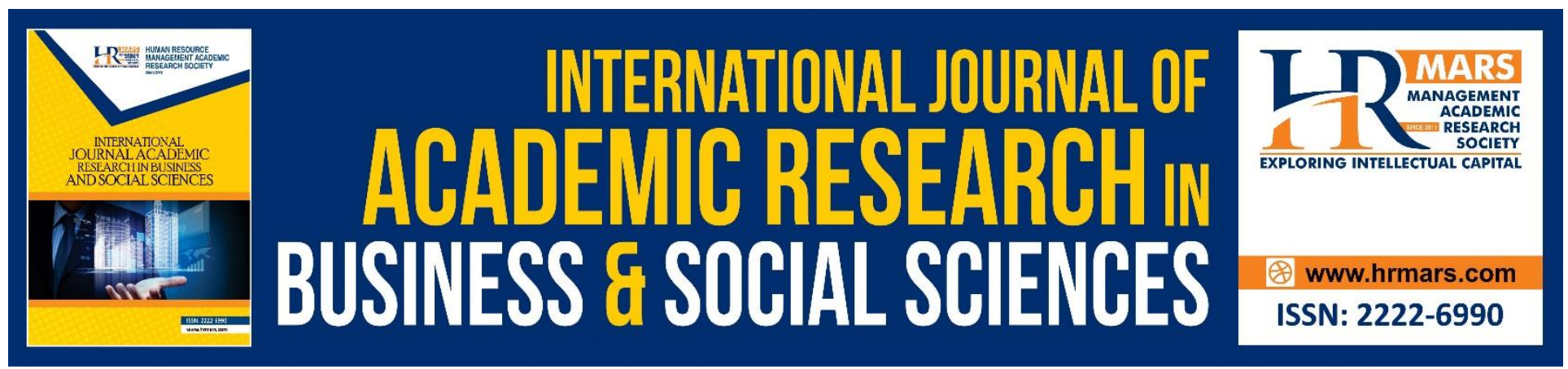

\title{
The Conditions for the Term maqbu/for Ibn Hajar in his Work Taqrib al-Tahzib
}

Helimy Aris, Nazri Muslim

To Link this Article: http://dx.doi.org/10.6007/IJARBSS/v8-i7/4334

DOI: $\quad 10.6007 /$ IJARBSS/v8-i7/4334

Received: 24 June 2018, Revised: 19 July 2018, Accepted: 29 July 2018

Published Online: 04 August 2018

In-Text Citation: (Aris \& Muslim, 2018)

To Cite this Article: Aris, H., \& Muslim, N. (2018). The Conditions for the Term maqbul for Ibn Hajar in his Work Taqrib al-Tahzib. International Journal of Academic Research in Business and Social Sciences, 8(7), $187-195$.

Copyright: (C) 2018 The Author(s)

Published by Human Resource Management Academic Research Society (www.hrmars.com)

This article is published under the Creative Commons Attribution (CC BY 4.0) license. Anyone may reproduce, distribute, translate and create derivative works of this article (for both commercial and non-commercial purposes), subject to full attribution to the original publication and authors. The full terms of this license may be seen

at: http://creativecommons.org/licences/by/4.0/legalcode

Vol. 8, No. 7, July 2018, Pg. 187 - 195

http://hrmars.com/index.php/pages/detail/IJARBSS

JOURNAL HOMEPAGE

Full Terms \& Conditions of access and use can be found at http://hrmars.com/index.php/pages/detail/publication-ethics 


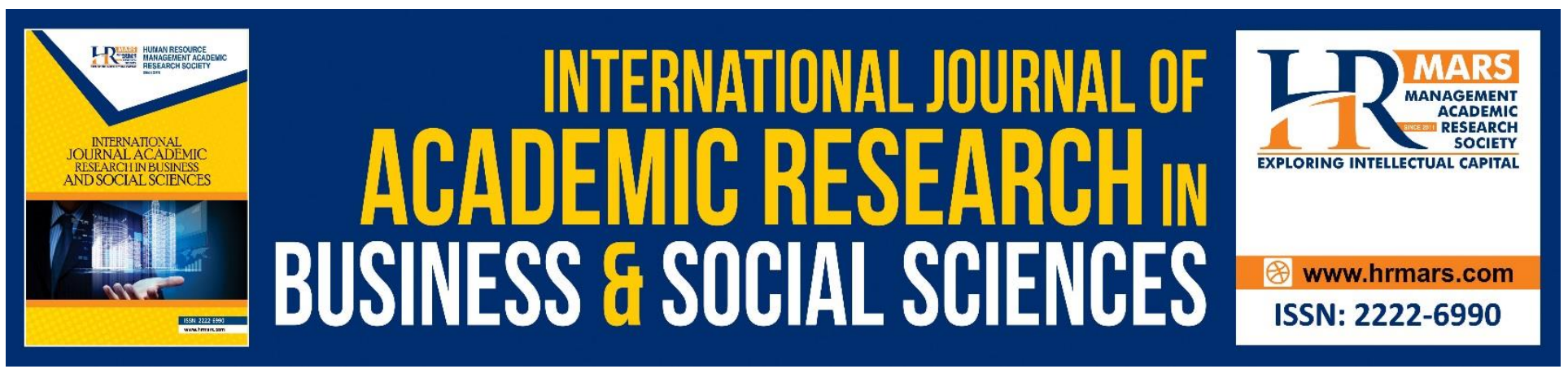

\title{
The Conditions for the Term maqbu/for Ibn Hajar in his Work Taqrib al-Tahzib.
}

\author{
Helimy Aris \\ Faculty Quranic and Sunnah Studies, Islamic Science University of Malaysia, Malaysia \\ Nazri Muslim \\ Centre for Citra, National University of Malaysia, Malaysia \\ Email:nazrimuslim@yahoo.com
}

\begin{abstract}
This study concerns with the condition mentioned by Ibn Hajar for one of the terms that he decided to use in his academic work entitled Taqrib al-Tahzib. This is carried out to see the extent of Ibn Hajar's firm decision to follow the conditions when evaluating the hadith narrators of al-kutub alsittah. To realise this, the writer has adopted the qualitative methodology which is by delving into every angle required, related to all narrators characterised by Ibn Hajar as maqbul in his three last tabaqahs namely tabaqah no. 10, tabaqah no. 11 and tabaqah no. 12 together with all their narrations contained in al-kutub al-sittah and the printed mulhaqat al-kutub al-sittah only.
\end{abstract}

Keywords: Maqbul, Ibn Hajar, Narrators, Taqrib al-Tahzib, hadith

\section{Introduction}

One of the simple references when it comes to identifying the status of the hadith narrators of alkutub al-sittah is the book Taqrib al-Tahzib arranged by al Hafiz Ibn Hajar al-Asqalani (852H). Maqbul is the term used by him for the sixth degree narrators of al-kutub al-sittah. They are divided into twelve tabaqahs. Every tabaqah refers to one generation of narrators.. The last three tabaqahs are specifically reserved for the generation of taba 'atba` al tabi in who normally died after two hundred years of hijriyyah. There are one hundred and fifteen narrators in these three tabaqahs regarded by Ibn Hajar as maqbul. This is not considering those narrators also characterised as maqbul but are not hadith narrators in al-kutub al-sittah and mulhaqat of al-kutub al-sittah or whose hadiths contained in the unprinted mulhaqat al-kutub al-sittah.

In the foreword of al Taqrib, Ibn Hajar has issued three conditions for the term maqbul namely:

i. Narrators characterised as maqbul must be qalil al-riwayah (few narrative works).

ii. There is no flaw that causes the narration to be rejected.

iii. There is a mutabi for his narration which means there is the same narrator reporting the same hadith through another source. 
Among the studies related to the term maqbul is that of Husban (2005). His study was limited to the narrators of maqbul who narrated the hadith in al-Mukhtarah li al-Diya al-Maqdisi. Another study was conducted by Jitan (2010). But it is only related to the maqbul narrators in the second and third tabaqah. The study should be done on the maqbul narrators in the other tabaqah to get a comprehensive decision on Ibn Hajar's escalation to the conditions of maqbul he has set. To fulfill this requirement, the author has done this study.

After collecting and studying the comments given by the members of jarh wa ta'dil towards all maqbul narrators in the last three tabaqahs also the hadiths that they have reported in al-kutub alsittah and the printed mulhaqat al-kutub al-sittah, the writer has come to several findings as follows:

\section{The First Condition}

The study has shown that almost all of the maqbul narrators in the last three tabaqahs do not have any of the features other than few narrations, which is altogether one to three hadiths other than eleven narrators namely:

1- Yahya bin Qaza`ah ( he has reported twenty seven hadiths)

2- Muhammad bin Daud al-Masisi (he has reported twelve hadiths)

3- Musa bin Marwan (he has reported eleven hadiths)

4- Harun bin Abbad (he has reported six hadiths).

5- Abd Rahman bin Aswad (he has reported six hadiths).

6- Ibrahim bin Mahdi (he has reported five hadiths).

7- Abd Rabbih bin Khalid (he has reported five hadiths).

8- Muhammad bin Sa id (he has reported five hadiths).

9- Ali Bin Isa (he has reported five hadiths).

10- Rifa'ah bin Haitham (he has reported four hadiths).

11- Ahmad bin Ja'far (he has reported four hadiths).

If we were to compare the number above (11) with the number 104 indicating the number of narrators who have one to three hadiths only, it shows that this first condition qillat al-riwayah is very significant to maqbul narrators in the last three tabaqahs.

There are several names mentioned by Ibn Hajar in the last three tabaqahs that have not narrated any hadiths. Some only issue the statements given by a number of salafus soleh and some others are briefly mentioned in certain narrations. The narrators in tabaqah no. 12 are the least to be characterised as maqbul, which total six narrators only.

\section{The relation between Qillah Al-Riwayah and Al-Wuhdan}

The study outcome also shows that the narrators with students more than one total ninety four or eighty three percent (83\%). From this number, forty of them are narrators who have students holding the status of hadith-screening imam (al-Imam al-Muntaqi li al-Ahadith).

Narrators with only one student or known as al-Wuhdan total twenty one or seventeen percent (17\%). From this number, eleven are narrators who have students holding the status of hadithscreening imam (Refer to Diagram 1). 


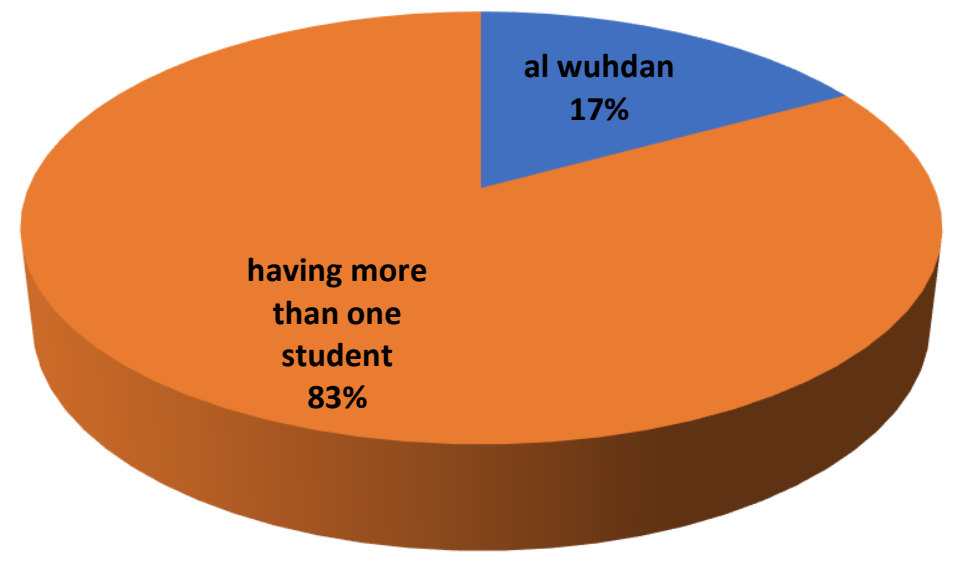

Diagram 1: The percentage of maqbul based on the total number of student.

The study outcome shows that there is no clear relation between qillah al-riwayah and al-wuhdan. Thus, it is imprecise to say that most of the maqbul narrators are wuhdan or in other words, qillah alriwayah is not the reason behind al-wuhdan as claimed by al-Aniy (1999).

\section{The second condition}

The study highlights that reputable narrators (thiqah) total sixty eight or fifty nine percent (59\%) (Refer to Diagram 2).

Among these trusted narrators, sixteen of them or twenty four percent (24\%) - are narrators evaluated as endorsed by jarh wa ta' dil and at the same time they have their own hadith-screening students or imams (al-imam al muntaqi). Twenty three more students or thirty four percent (34\%) are regarded as trusted by members of jarh wa ta'dil but without them having hadith-screening students (Refer to Diagram 3). From this number, ten of them are endorsed as trusted by al-Zahabi only. They are respectively from Ibn Hibban and al-Haithami and they have acknowledged one as the trusted one. Meanwhile, another one has his hadith narrated in Sahih Ibn Hibban. The remaining ten narrators or less than half have been evaluated as trusted by members of jarh wa ta'dil other than Ibn Hibban, al-Zahabi and al-Haithami.

There are twenty nine or forty three percent (43\%) who escape any of the comments from members of jarh wa ta'dil but regarded by the writer as trusted by way of considering the status of the students who can screen hadiths and elevate themselves as imam (Refer to Diagram 3).

The study further shows that there are eight weak narrators, or seven percent (7\%). For narrators with unknown status (majhul) they constitute thirty nine narrators or thirty four percent (34\%) (Refer to Diagram 2). 


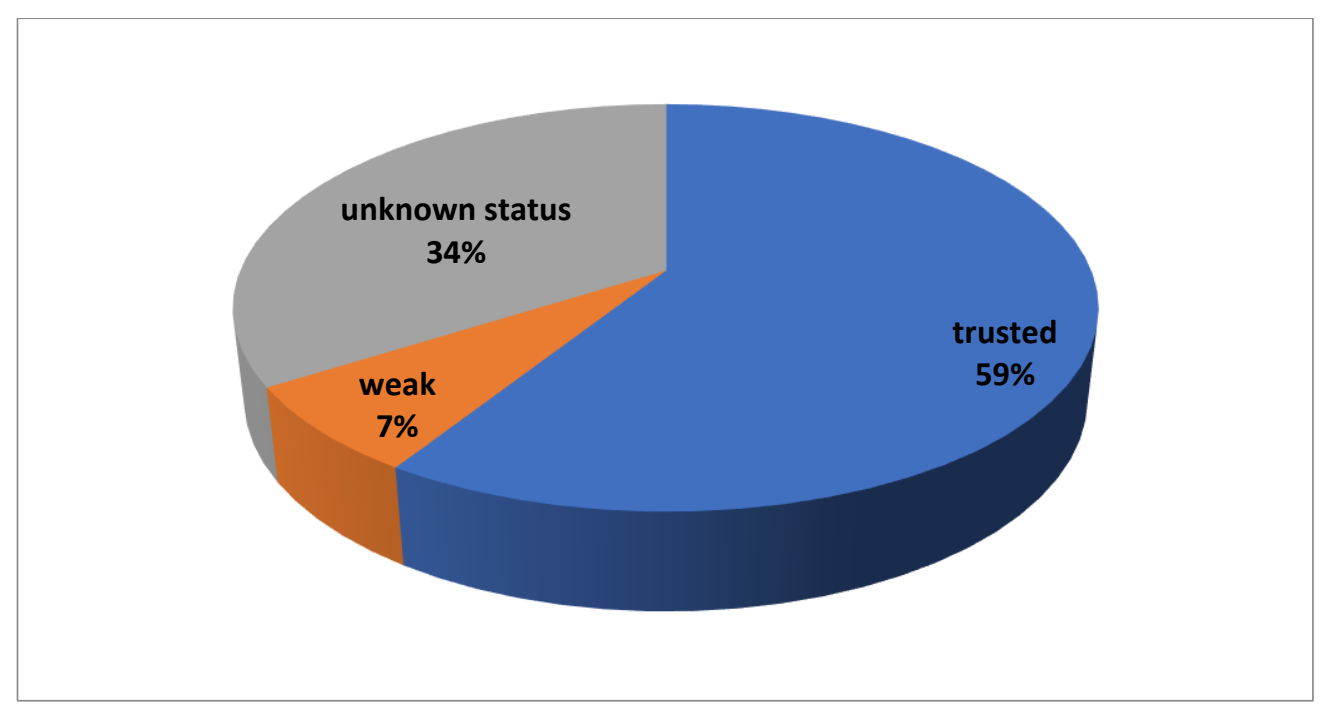

Diagram 2: The percentage of maqbul based on the status of every narrator

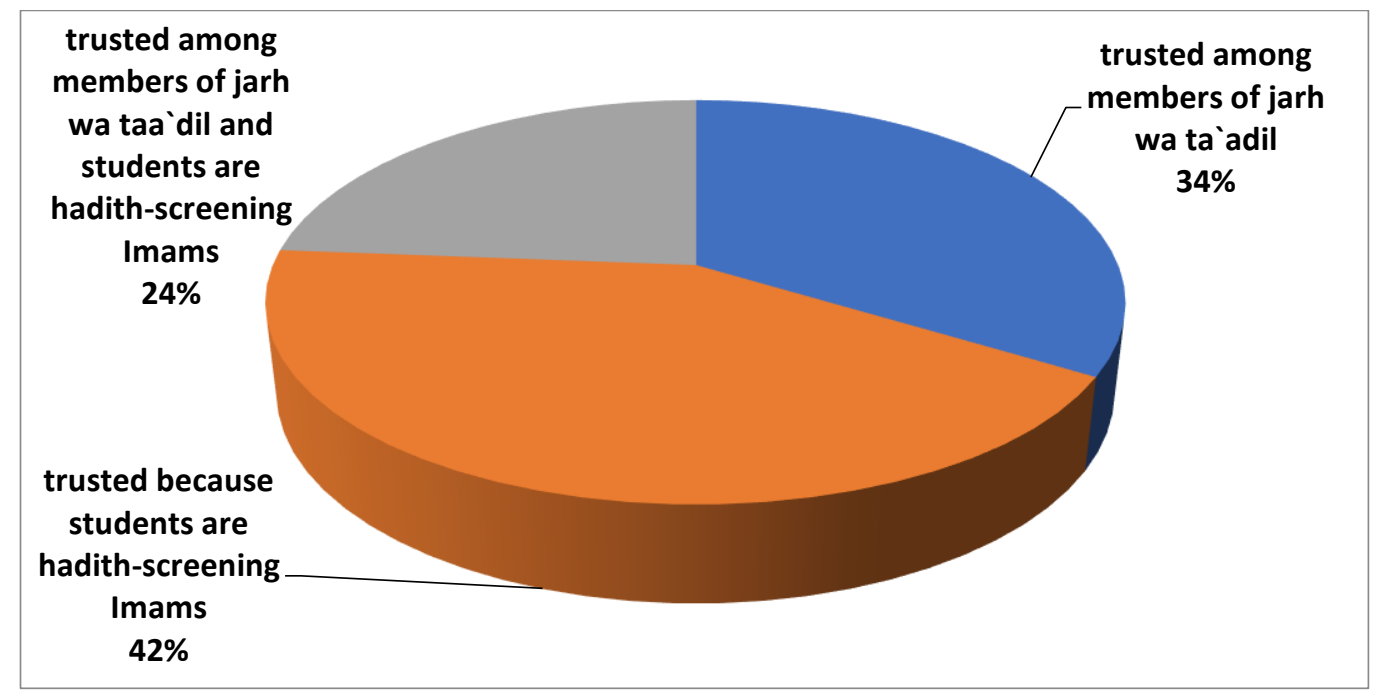

Diagram 3: The percentage of thiqah maqbul based on asbab tauthiq

In the opinion of your writer, Ibn Hajar does not consider tauthiq (assessment) of Ibn Hibban, alZahabi and al-Hathami in assessing a small fraction of maqbul narrators from the last three tabaqahs. However, he is seen to have considered the comments of al-Zahabi and Ibn Hibban in various circumstances.

This can be understood through two aspects:

i. The relationship between maqbul narrators and those mentioned by Ibn Hibban in al-Thiqat.

ii. The stance of al-zahabi towards maqbul narrators.

The Relationship between Maqbul narrators and narrators Mentioned by Ibn Hibban In Al-Thiqat.

None of the Maqbul narrators from tabaqah twelve has been mentioned by Ibn Hibban in alThiqat. The total number of Maqbul narrators from tabaqah ten and eleven mentioned by Ibn Hibban in al-Thiqat are forty four people or thirty eight percent (38\%). This means that the remaining Maqbul narrators from both tabaqahs or sixty two percent (62\%) are not mentioned by Ibn Hibban in al- 
INTERNATIONAL JOURNAL OF ACADEMIC RESEARCH IN BUSINESS AND SOCIAL SCIENCES Vol. 8, No. 7, July 2018, E-ISSN: 2222-6990 @ 2018 HRMARS

Thiqat. It can be concluded that most of the narrators labelled as maqbul (which is also another term for majhul in Taqrib al-Tahzib) y lbn Hajar in the last three tabaqahs are narrators not mentioned by Ibn Hibban in al-Thiqat (Refer to Diagram 4).

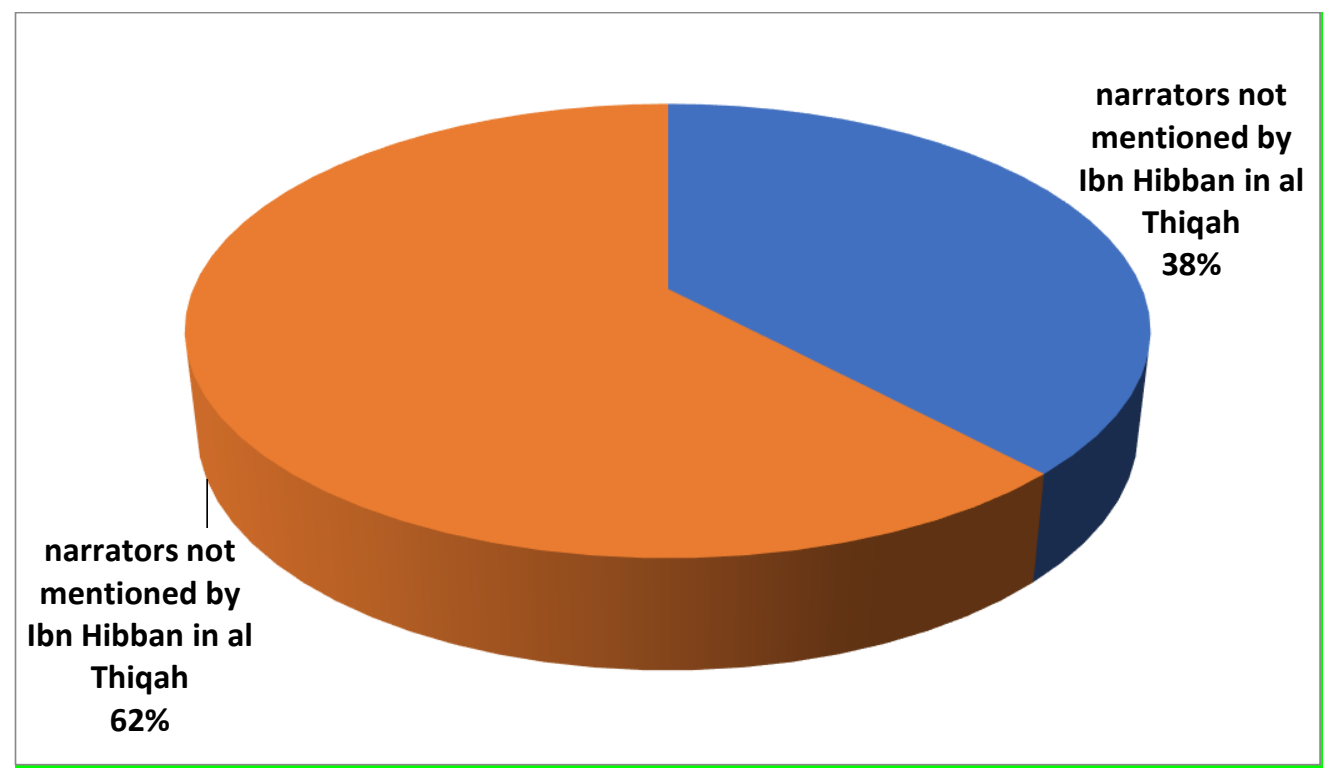

Diagram 4: The percentage of maqbul based on al-Thiqat Ibn Hibban.

\section{The Stance of Al-Zahabi Towards Maqbul narrators}

Al-Zahabi has some diverse opinions on Maqbul narrators. Some of them have been assessed by him as trusted. Some others have been assessed by him as weak. Some are assessed as majhul. Some are of the opinion that he is not consistent. Nonetheless, most Maqbul narrators in the last three tabaqahs are devoid of al-Zahabi's commentary. These are the details:

Narrators assessed as thiqah by az Zahabi = twenty three $(20 \%)$

Narrators assessed as weak by az Zahabi = three (3\%)

Narrators assessed as majhul by Az Zahabi = thirteen (11\%)

Narrators of whom the opinions of az Zahabi keep changing $=$ one (1\%)

Narrators on whom az-Zahabi's stance is not mentioned= seventy four (64\%)

There is a narrator mentioned by Az Zahabi and he states that Imam Muslim has narrated his hadith in a maqrun manner (Refer to Diagram 5). 
INTERNATIONAL JOURNAL OF ACADEMIC RESEARCH IN BUSINESS AND SOCIAL SCIENCES Vol. 8, No. 7, July 2018, E-ISSN: 2222-6990 @ 2018 HRMARS

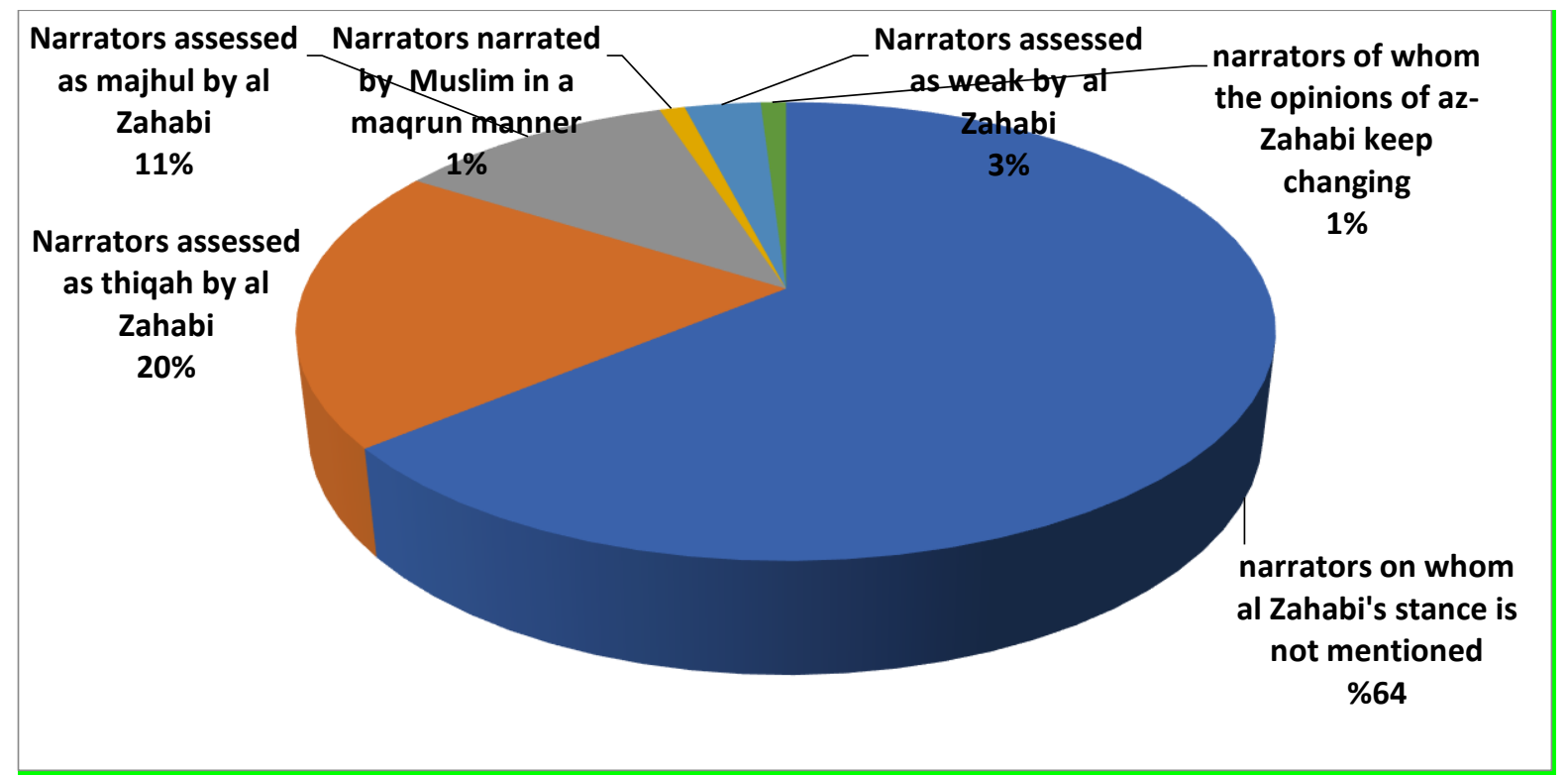

Diagram 5: The percentage of maqbul based on the assessment of al-Zahabi

In the writer's view, Ibn Hajar does not assess the Maqbul narrators in the last three tabaqahs as thiqah alone, due to the fact that their students or scholars are hadith-screening Imams. In turn, he has characterised themselves as maqbul if there is no ta'dil from members of jarh wa ta'dil. Meanwhile, maqbul in Taqrib al-Tahzib also means majhul (Helimy, 2018). If their total number is added to the number of narrators who are indeed majhul, there will be sixty eight people or fifty nine percent (59\%). This still shows that there is a consistency between this second condition with the comments of Ibn Hajar towards Maqbul narrators in the last three Tabaqahs.

\section{The Third Condition}

Narrators with the line of narration supported (mutaba ) constitute ninety three persons or eighty one percent (81\%). Meanwhile, for narrators whose line of narration is not supported but the meaning of hadiths is supported (or mentioned as syahid) they make up five persons or four percent (4\%). Narrators who are not supported (in terms of the narration and meaning of hadiths) constitute seventeen people or fifteen percent (15\%). The outcome shows that there is a consistency between this condition and the commentary made by Ibn Hajar towards the narrators. It can become a strong basis to support Al-Jitan's opinion (2010), stating that mutaba 'ah determined by Ibn Hajar serves as maqbul condition or which means mutaba ah according to the term used by hadith members. This conflicts with the opinion of al-Husban (2005) stating that mutaba'ah in Taqrib al-Tahzib also includes syawahid. The study outcome is also opposing the opinion of al-Aniy (1999) where it states that mutaba 'ah is not part of the maqbul condition to Ibn Hajar (Refer to Diagram 6). 
INTERNATIONAL JOURNAL OF ACADEMIC RESEARCH IN BUSINESS AND SOCIAL SCIENCES

Vol. 8, No. 7, July 2018, E-ISSN: 2222-6990 @ 2018 HRMARS

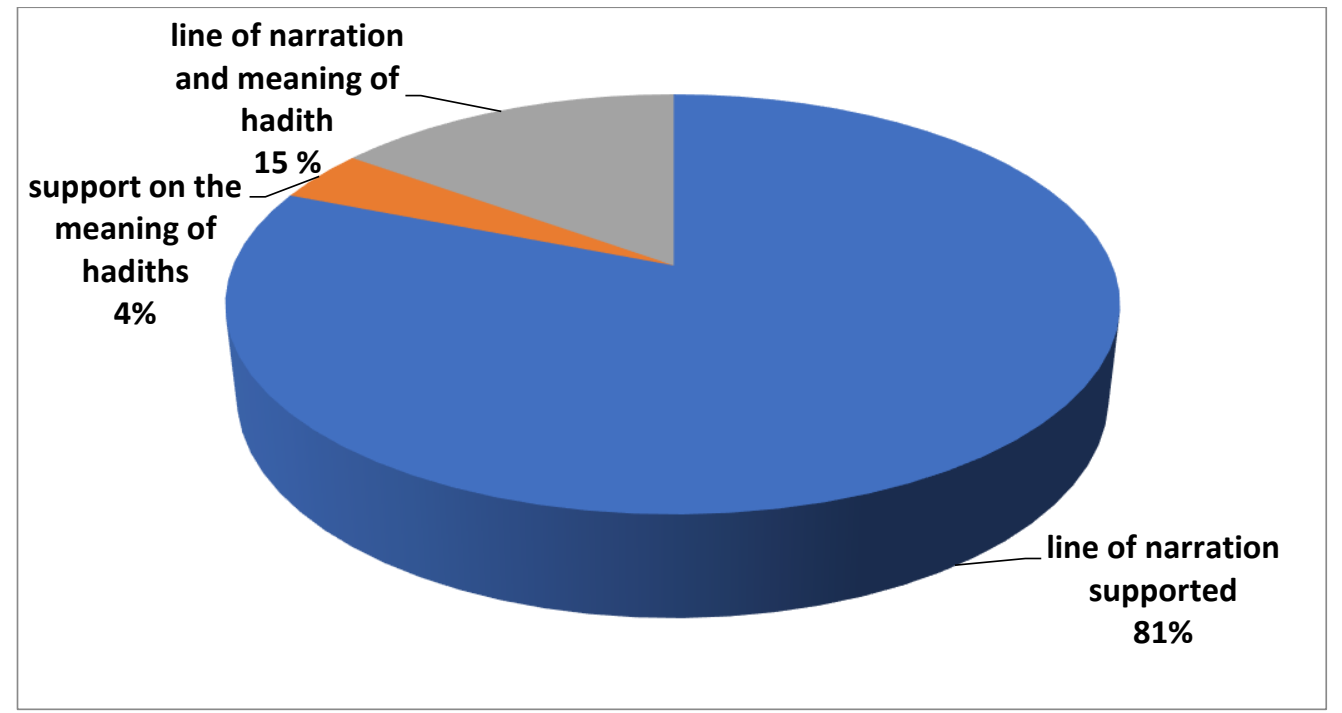

Diagram 6: The percentage of maqbul based on al-Mutaba 'at and al-Syawahid

\section{The Number of Hadiths for Maqbul Narrators}

The number of hadiths narrated by all maqbul narrators of the last three tabaqahs total two hundred and nineteen hadiths. From that number, sahih hadiths constitute one hundred and twenty nine or particularly fifty nine percent (59\%) out of the total number of hadiths. Hasan hadiths make up thirty nine hadiths or eighteen percent (18\%). Daif hadiths total fifty one hadiths or twenty three percent (23\%). The study outcome shows that most of the hadiths narrated by maqbul narrators can serve as an argument in Syara'. If we are to add the number of sahih and hasan hadiths, the number of hadiths that can serve as shara' are one hundred sixty eight hadiths or seventy seven percent (77\%) (Refer to Diagram 7).

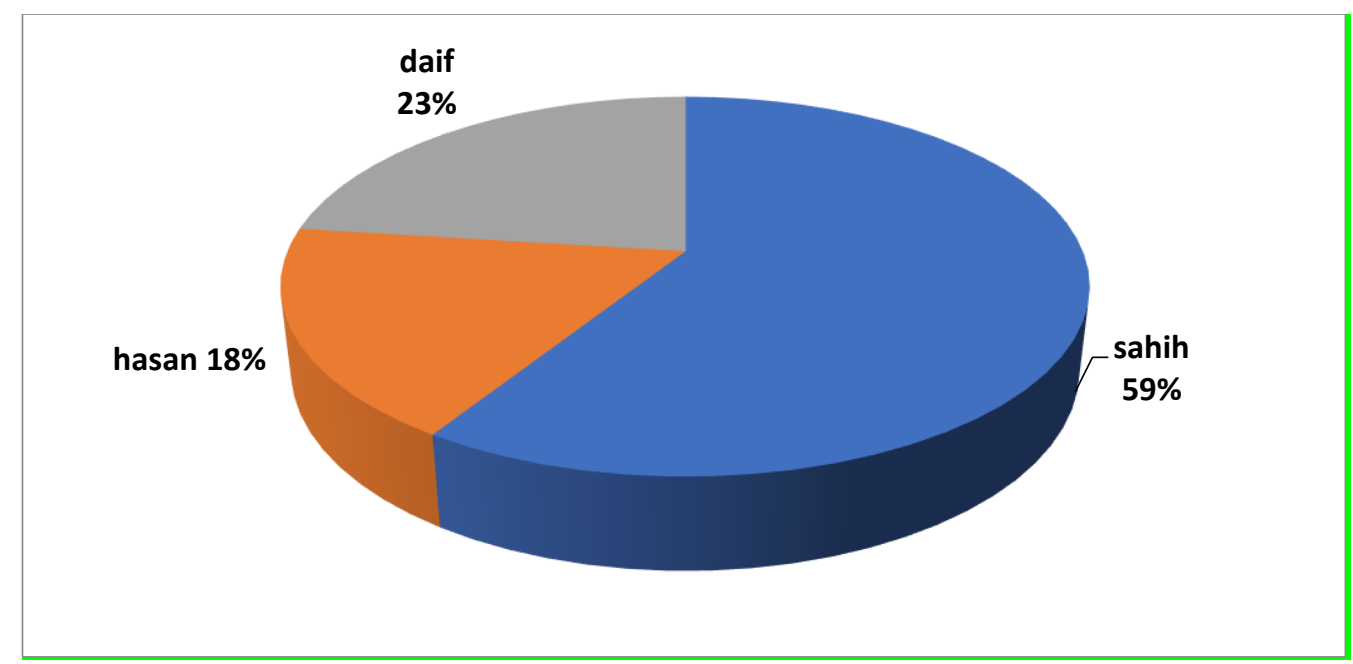

Diagram 7: The percentage of hadiths from maqbul narrators based on the status of every hadith.

\section{Conclusion}

Qillah al-riwayah is a significant feature of all maqbul narrators in the last three tabaqah. It can not be attributed consistently to tafarrud and wuhdan. Although there are some narrators are thiqah among the maqbul narrators of the last three tabaqah, but their majority are majhul. There is a strong 
INTERNATIONAL JOURNAL OF ACADEMIC RESEARCH IN BUSINESS AND SOCIAL SCIENCES

Vol. 8, No. 7, July 2018, E-ISSN: 2222-6990 @ 2018 HRMARS

influence from Ibn Hibban and al-Zahabi's writings on Ibn Hajar's assessment, particularly in the last three maqbul narrators. All of the studies show the consistency between the maqbul conditions in Taqrib al-Tahzib and Ibn Hajar's comment on the maqbul narrators in the last three tabaqahs with quite a significant percentage. This illustrates that Ibn Hajar is someone who is very consistent in his views and he is also highly credible in al-Jarh wa al-Ta'dil. The authors recommend that qualitative studies be continued against the maqbul narrators in tabaqah-tabaqah that have not been conducted any study or have done but not in detail so that a comprehensive and accurate decision on Ibn Hajar's invasion of its terms can be found.

\section{References}

Aniy, W. (1999). Manhaj Dirasah al-Asanid. Jordan: Dar an-Nafais.

Asaqir, I. (1981). Al-Mu jam al-Musytamil. Beirut: dar al-Fikr.

Asqalani, I (1986). Taqrib al-Tahzib. Syria: Dar ar-Rasyid.

Bukhari, M. (2001). Sahih al-Bukhari. Beirut: Dar Touq an-Najah.

Busti, I. (1973). Al-Thiqat. India: Dairah al-Maarif al-usmaniyyah.

Helimy, A. (2018). Lafz Maqbul Inda al-Hafiz Ibn Hajar fi Kitabihi Taqrib al-Tahzib Dirasah Naqdiyyah ala Maqbuli al-Tabaqah al-Asyirah wa al-Hadiah asyarah wa al-Thaniah asyarah. Nilai: USIM.

Husban, K. (2005). Ar-Rawi al-Maqbul. Jordan: Yarmouk University.

Jitan, M. (2010). Mustalah Maqbul. Palestin: al-Najah al-Wataniyyah University.

Naisaburi, M. (1954). Sahih Muslim. Beirut: Dar Ihya`al-Turath.

Nasa`I, A. (1986). Sunan Al-Nasa i. Halab: Maktab al-Matbu’at al-Islamiyyah.

Qazwini, I. (2009). Sunan Ibn Majah. Beirut: Dar al-Risalah al-Alamiyyah.

Sijistani, A. (2009). Sunan Abi Daud. Beirut: Dar al-Risalah al-Alamiyyah.

Tirmizi, M. (1998). Sunan Al-Tirmzi. Beirut: Dar al-Gharb al-Islami.

Zahabi, M. (1985). Al-Kasyif. Jeddah: Muassasah Ulum al-Quran. 